\title{
In Vitro Propagation of Lilium Iongiflorum Bulbs Using NAA and BAP Plant Growth Regulator Treatment
}

\section{Ni Wayan Deswiniyanti and Ni Kadek Dwipayani Lestari}

Faculty of Health, Science and Technology, Dhyana Pura University, Badung, Bali 80361

\section{Abstract}

Lily (Lilium longiflorum) is a perennial herbaceous plant with white trumpet-shaped flowers, fragrant and bulbous. In vitro culture through bulbs is one of way propagation of lily plants, but it requires a long time and only produces limited plants. In vitro propagation is a very promising technique for plant propagation because it can produce a lot of plant seeds in a short time. Bulbs are one of the fastest explants for growing shoots in lilies, but it is not known for certain which cuts of explants from bulb scales are best for multiplying in vitro. This study aims to determine the effect of lily bulb explants and the concentration of NAA and BAP growth regulators on the

Corresponding Author: Ni Kadek Dwipayani Lestari deswiniyanti@undhirabali.ac.id

Received: 1 February 2020 Accepted: 8 February 2020 Published: 16 February 2020

Publishing services provided by Knowledge E

(c) Ni Wayan Deswiniyanti and $\mathrm{Ni}$ Kadek Dwipayani Lestari. This article is distributed under the terms of the Creative Commons

Attribution License, which

permits unrestricted use and redistribution provided that the original author and source are credited.

Selection and Peer-review under the responsibility of the IC-BIOLIS Conference Committee.

\section{G OPEN ACCESS} growth of lily bulb explants. The best results were obtained on the base and middle cuts explant of bulb scales compared to the tip cuts explant ones. The best results of the growing percentage, the number of shoots and the best growing time are shown in the combination treatment of growth regulator $1 \mathrm{mg} \mathrm{L}^{-1} \mathrm{NAA}$ and $1 \mathrm{mg} \mathrm{L}^{-1}$ BAP. The optimum results on the number of micro bulbs were found in the treatment of growth regulators $0.5 \mathrm{mg} \mathrm{L}^{-1} \mathrm{NAA}$ and $1 \mathrm{mg} \mathrm{L}^{-1}$ BAP. The best results of the average time formed micro bulb was in the treatment of $1 \mathrm{mg} \mathrm{L}^{-1}$ NAA and BAP with middle explant cuts, and treatment concentrations of $0.5 \mathrm{mg} \mathrm{L}^{-1}$ NAA and BAP in the base explant section. The base and middle bulb explants are able to regenerate or grow higher shoots. This is caused by the presence of endogenous natural auxin and the spread of auxin in plant parts not in the same amount. Therefore when added to the exogenous growth regulator such as auxin or cytokines to culture media will further trigger the formation of micro tubers more quickly,. It can increase the concentration of endogenous growth regulators in cells, help growing process and developing tissue.

Keywords: Bulb, lily, micro bulbs, in vitro, shoots

\section{Introduction}

Lily plants (Lilium Spp.) are plants known as cut flowers and commonly used in flower arrangements and room decorations [1]. Several types of lily such as Lilium longiflorum, Lilium speciosum, and Lilium aurateum have long been cultivated in mountainous areas in Java as ornamental plants in the yard [2] However, the idea of lily flowers as a commercial business in Indonesia has only just begun to be developed in the last 
decade. The development is based on a very good prospect, due to the diversity of lily colors, good ability to adapt to the environment, ease of cultivation techniques, and lower production costs compared to other cut flowers, such as chrysanthemums. Along with the development of lily cut flowers, there has been an increase in demand for lily sprout [3]

Lily is a true bulb plant, in the shape of a cup surrounded by scales that functions as a food reserve containing starch, sugar and protein. Scale resembles a thin fleshy sheet and can be easily separated and grown into new shoots and plants (Crocket, 1973). Lily is commercially propagated through bulbs, while lily for bulb production is propagated through the vegetative part of the plant i.e. scales, prospective bulbs (bulblets) that grow on the rootstock of plants and by tissue culture techniques [1]. The use of tissue culture is very helpful in the commercial production process because the process of planting lily in the field can only be done in areas that support the climate during the planting process, otherwise it can prevent the infectious diseases in the propagation results.

The use of in vitro techniques for the development of lily cut flowers in Indonesia is greatly possible. Robb [4], and Takayama and Misawa [5] succeeded to induce bulblets in the culture of lily bulb scales. Several previous studies also reported factors influencing in vitro lily culture, namely the composition of growth regulators ([5];[6];[7]), explant sections ([4];[6]), and explant positions [8].

Growth induction using growth regulators is widely reported ([9];[10];[11]). It was further reported that the combination of auxin and cytokinin gave the best results in inducing micro potato bulbs of Kufru Jyoti varieties [12]

The best explants that can be used for growing shoots and micro bulbs are bulb explants. However, it is currently still uncertain which cuts of bulb scales give the best results. In addition, the effectiveness of using hormone concentration on the speed of growth of lily bulb scales is also uncertain. This study aims to determine the best potential of the bulb scales cuts and hormone concentrations, as well as the effect of temperature treatment on growing time, growing percentage, number of shoots, number of micro bulbs and the formation time of micro bulbs.

\section{Method}




\subsection{Time and Place of Research}

The study was conducted in February 2019-July 2019 at the tissue culture laboratory at Crops Seed Center Hall, Luwus, Tabanan Regency, Bali Province.

\subsection{Media Preparation}

The in vitro culture media used in this experiment is Vacin and Went media supplemented with $20 \mathrm{~g} . \mathrm{L}^{-1}$ sucrose and $8 \mathrm{~g} . \mathrm{L}^{-1}$ agarose. Various combinations of NAA and BAP were used as treatments, consisted of combination of NAA and BAP growth regulators, namely a) 0.5 mg.L-1 NAA + 0.5 mg.L-1 BAP; b) 0.5 mg.L-1 NAA + 1 mg.L-1 BAP; c) $1 \mathrm{mg} . \mathrm{L}-1 \mathrm{NAA}+0.5 \mathrm{mg} . \mathrm{L}-1 \mathrm{BAP}$; d) $1 \mathrm{mg} . \mathrm{L}-1 \mathrm{NAA}+1 \mathrm{mg}$.L-1 BAP. The $\mathrm{pH}$ of the media was adjusted at 5.6-5.8 before autoclaving at $121^{\circ} \mathrm{C}$ and 15 psi for 15 minutes. Innoculated explants were incubated in the culture room at $25^{\circ} \mathrm{C}$ and cool-white fluorescent lamps with $16 \mathrm{~h}$ photoperiod under.

\subsection{Explant Sterilization}

The lily bulbs were separated by scales one by one and then washed with running water and soaked in a fungicide solution for 30 minutes. Furthermore, the explants were soaked in $20 \%$ and $10 \%$ chloric solution each for 15 minutes then rinsed with sterile aquades 3 times. Sterilized explants were planted on Vacin \& Went (VW) culture media with various treatments by adding a combination of NAA and BAP growth regulators that had been sterilized with a 15 psi autoclave for 30 minutes. The culture bottles which had been planted with explants were incubated in the culture room where the temperature was maintained between $26-28^{\circ} \mathrm{C}$ with 2000 lux irradiation for 16 bright hours and 8 hours without irradiation.

\subsection{Research Design}

The study used a Completely Randomized Design with Factorial pattern consisting of three factors. The first factor was explant cuts consisting of 3 parts, namely the base, middle and tip. The second factor consisted of administering a combination of NAA and BAP growth regulators, namely a) $0.5 \mathrm{mg} \mathrm{L}^{-1} \mathrm{NAA}+0.5 \mathrm{mg} \mathrm{L}^{-1} \mathrm{BAP}$; b) $0.5 \mathrm{mg}$ $\mathrm{L}^{-1} \mathrm{NAA}+1 \mathrm{mg} \mathrm{L}^{-1} \mathrm{BAP}$; c) $1 \mathrm{mg} \mathrm{L^{-1 }} \mathrm{NAA}+0.5 \mathrm{mg} \mathrm{L}^{-1} \mathrm{BAP}$; d) $1 \mathrm{mg} \mathrm{L}^{-1} \mathrm{NAA}+1$ $\mathrm{mg} \mathrm{L}^{-1}$ BAP. Therefore, there were 10 treatment combinations with 3 replications. The 


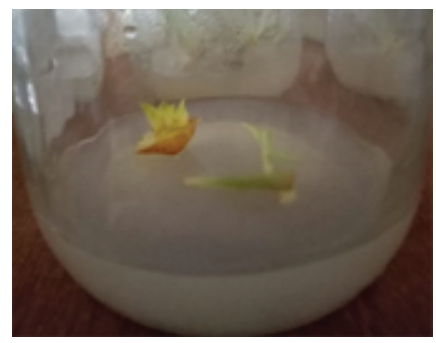

Figure 2: Micro bulbs.

Based on observations, concentrations of NAA and BAP growth regulators that the results of the growth percentage, the number of shoots and the best growing time are shown in the combination treatment of $1 \mathrm{mg} \mathrm{L}^{-1} \mathrm{NAA}$ and $1 \mathrm{mg} \mathrm{L}^{-1}$ BAP. The results of the number of micro bulbs are shown in the treatment of $0.5 \mathrm{mg} \mathrm{L}^{-1} \mathrm{NAA}$ and $1 \mathrm{mg} \mathrm{L}^{-1}$ BAP. The results of the average time to form micro bulbs are in the treatment of $1 \mathrm{mg}$ $\mathrm{L}^{-1} \mathrm{NAA}$ and BAP with middle explant cuts and treatment concentrations of $0.5 \mathrm{mg} \mathrm{L}^{-1}$ NAA and BAP in the base explant section are presented in Table 2 and Figure 4.

TABLE 2: Observations based on concentrations of NAA and BAP growth regulators.

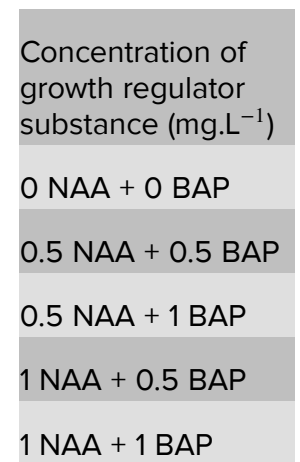

$\begin{gathered}\text { Growing } \\ \text { percentage }\end{gathered}$
$94^{a}$
$100^{b}$
$96.7^{a b}$
$100^{b}$
$100^{b}$

\begin{tabular}{c} 
Growing time \\
\hline $15.20^{a}$ \\
\hline $14.81^{a}$ \\
\hline $14.71^{a}$ \\
\hline $14.89^{a}$ \\
\hline $14.19^{a}$ \\
\hline
\end{tabular}

\begin{tabular}{l}
$\begin{array}{c}\text { Number of } \\
\text { shoots }\end{array}$ \\
\hline $2.25^{a}$ \\
$3.94^{b c}$ \\
$2.46^{a b}$ \\
$3.78^{b c}$ \\
$4.25^{c}$
\end{tabular}

\begin{tabular}{|c|}
\hline $\begin{array}{c}\text { Number of } \\
\text { micro bulbs }\end{array}$ \\
\hline $0^{a}$ \\
\hline $1.25^{b c}$ \\
\hline $1.70^{a b}$ \\
\hline $1.27^{b c}$ \\
\hline $1.40^{c}$ \\
\hline
\end{tabular}

$\begin{gathered}\text { Formation time } \\ \text { of micro bulbs }\end{gathered}$
$0^{a}$
$122^{c}$
$128.18^{b c}$
$120.57^{b c}$
$128.40^{b c}$

Note: The average value of the treatment followed by letters in the same column showed no significant difference based on Duncan's multiple range test at 5\% level.
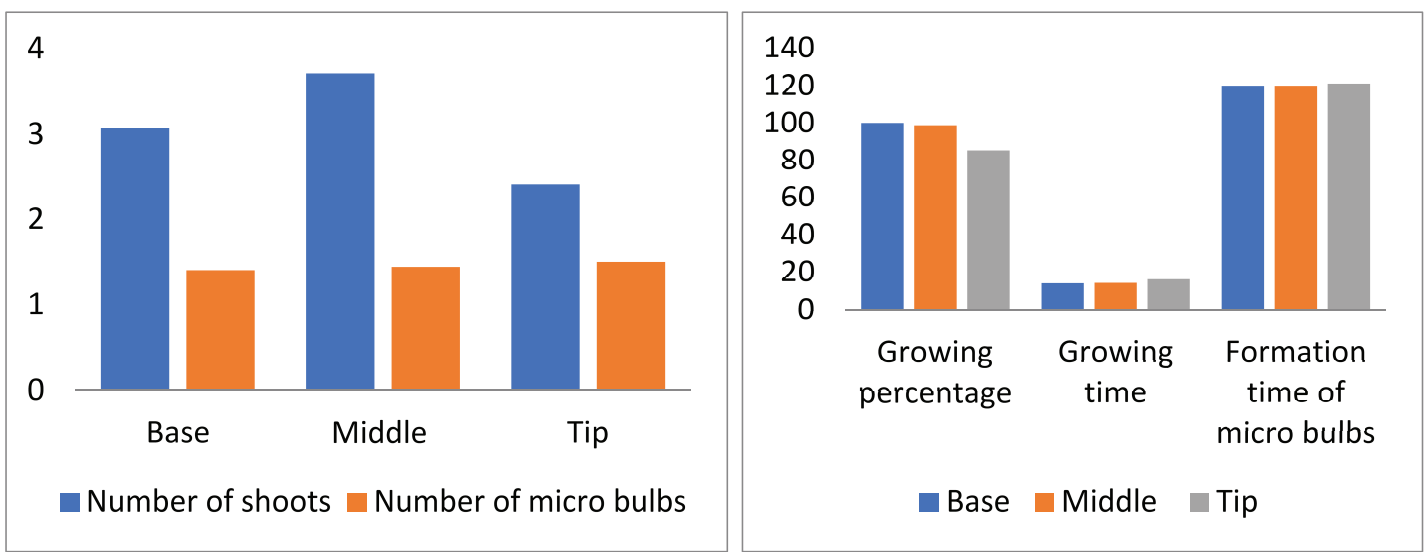

Figure 3: Graph of results based on cuts of bulb explants. 

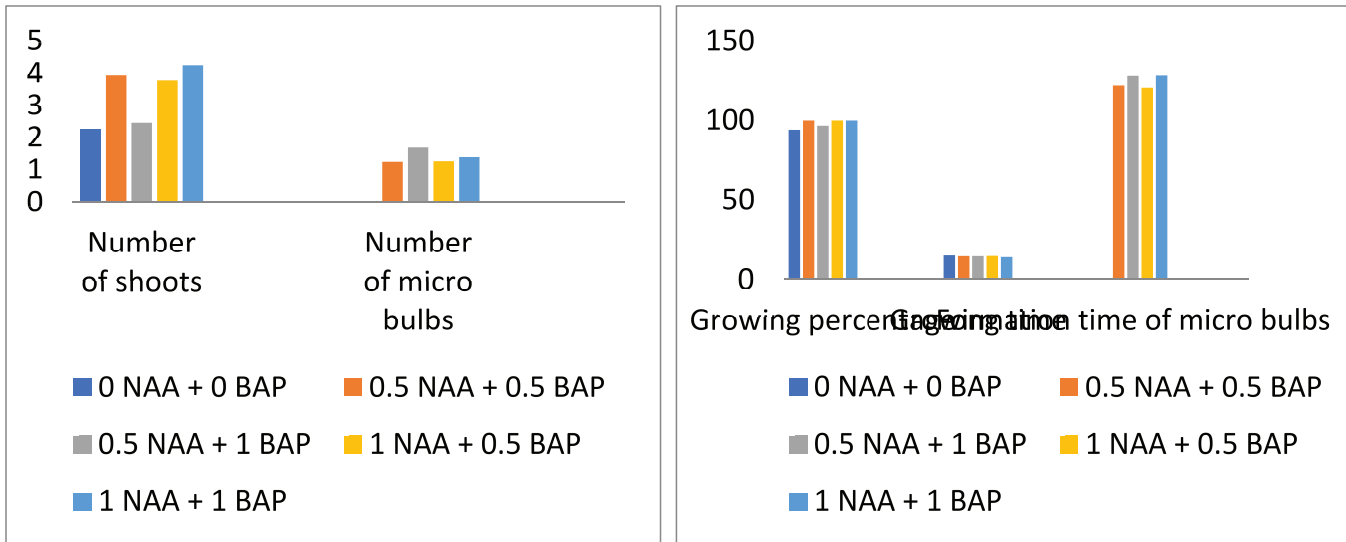

Figure 4: Graph of results based on concentrations of NAA and BAP growth regulators.

Interactions between explant cuts and growth regulator substance are presented in Table 3. In the test results, the relationship between explant cuts and concentration of growth regulators used the best percentage of growth in the treatment of middle bulb explant cuts with all concentrations of growth regulators. The interactions between the explant parts and the concentration of growth regulators in the variable of growing time show significantly different results from the average number of shoots at the $1 \mathrm{mg}$ treatment. The interaction between bulb explant cuts and the concentrations of growth regulators showed significantly different results with the average number of shoots at the highest concentration of $1 \mathrm{mg}$. The interaction bulb explant cuts with concentrations of growth regulators, the average number of micro bulbs was found in the treatment of $0.5 \mathrm{mg} \mathrm{L}^{-1} \mathrm{NAA}$ and $1 \mathrm{mg} \mathrm{L}^{-1}$ BAP with middle explant cuts. Based on the interactions between bulb explant cuts and concentrations of growth regulators, the average result of micro bulbs was formed in the treatment of $1 \mathrm{mg} \mathrm{L}^{-1} \mathrm{NAA}$ and BAP in middle bulb explants cuts, and in the treatment concentrations of $0.5 \mathrm{mg} \mathrm{L}^{-1} \mathrm{NAA}$ and BAP in the base explant cuts.

\section{Discussion}

\subsection{Growing percentage}

The best explants that can be used for growing shoots and micro bulbs are bulb explants, but which cuts of bulb scales give the best results and the use of hormone concentration on the speed of growth of lily bulb scales it is not known for certain. This statement confirmation with the earlier study from Kanchanapoom et al. [13] that bulb scales of lily have a high regeneration potential hence they are most commonly used as explants for vegetative propagation and an efficient protocol for shoot regeneration 
TABLE 3: Interactions between explant cuts and growth regulator substance.

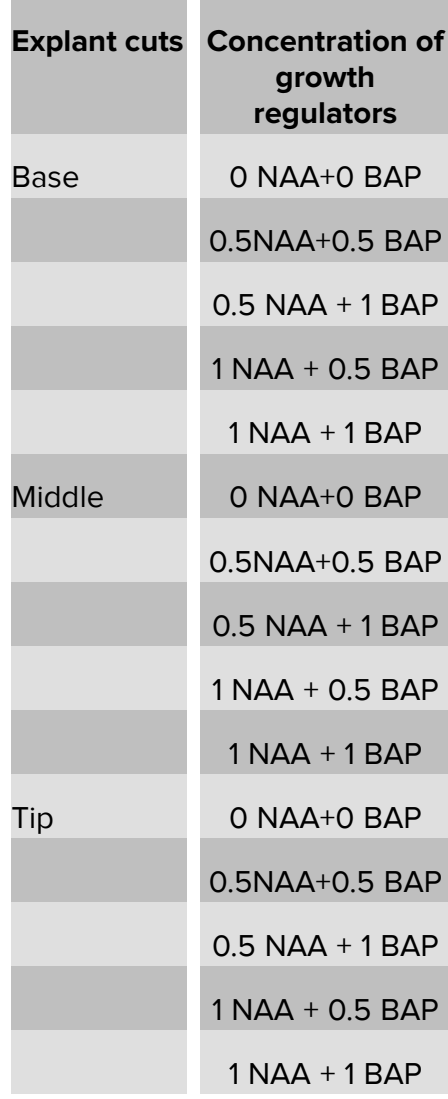

\begin{tabular}{|c|c|}
\hline $\begin{array}{c}\text { Growing } \\
\text { percentage }\end{array}$ & $\begin{array}{c}\text { Growing } \\
\text { time }\end{array}$ \\
\hline $96.67^{a}$ & $14.50 \mathrm{~b}$ \\
\hline $100.00^{b}$ & $14.50^{b}$ \\
\hline $96.67^{a}$ & $14.50^{b}$ \\
\hline $100.00^{b}$ & $14.17^{b}$ \\
\hline $100.00^{b}$ & $13.53^{a}$ \\
\hline $100.00^{b}$ & $14.75^{b}$ \\
\hline $100.00^{b}$ & $14.67^{b}$ \\
\hline $100.00^{b}$ & $14.50^{b}$ \\
\hline $100.00^{b}$ & $14.33^{b}$ \\
\hline $100.00^{b}$ & $13.75^{a}$ \\
\hline $83.33^{a}$ & $16.50^{d}$ \\
\hline $93.33^{a b}$ & $15.50^{c}$ \\
\hline $100.00^{b}$ & $15.33^{c}$ \\
\hline $100.00^{b}$ & $15.50^{c}$ \\
\hline $100.00^{b}$ & $14.83^{b}$ \\
\hline
\end{tabular}

\begin{tabular}{|c|}
\hline $\begin{array}{c}\text { Number of } \\
\text { shoots }\end{array}$ \\
\hline $2.50^{a}$ \\
$3.00^{b c}$ \\
$3.00^{b c}$ \\
\hline $4.17^{c}$ \\
\hline $4.67^{c}$ \\
\hline $2.38^{a}$ \\
\hline $2.50^{a b}$ \\
\hline $3.00^{b c}$ \\
\hline $2.83^{a b}$ \\
\hline $3.25^{c}$ \\
\hline $1.83^{a}$ \\
\hline $2.17^{b}$ \\
\hline $2.83^{c}$ \\
\hline $2.33^{c}$ \\
\hline $2.83^{c}$ \\
\hline
\end{tabular}

\begin{tabular}{c}
$\begin{array}{c}\text { Formation } \\
\text { time of } \\
\text { micro bulbs }\end{array}$ \\
$0^{a}$ \\
$121.67^{b}$ \\
$128.00^{b c}$ \\
$129.60^{c}$ \\
$129.33^{c}$ \\
$0^{a}$ \\
$123.00^{b}$ \\
$128.00^{c}$ \\
$124.00^{b}$ \\
\hline $121.67^{b}$ \\
$0^{a}$ \\
$0^{a}$ \\
$124.40^{b}$ \\
$128.50^{c}$ \\
$129.33^{c}$ \\
\hline
\end{tabular}

Note: The average value of the treatment followed by letters in the same column showed no significant difference based on Duncan's multiple range test at $5 \%$ level.

from bulb scales in L. longiflorum has been developed. The shoots occurred directly via organogenesis and without forming callus on MS medium containing BA and NAA.

Duncan's test shows significantly different results in the treatment of the explant cuts. The average percentage of the best growth from the treatment of explant cuts that is at the base and middle bulb explants compared to the tip explant cuts. It is suspected that endogenous auxin and cytokinin content in lily scales differ between tissue parts, so the percentage of regeneration produced in this study also varies depending on the direction of the explant cuts. This assumption is supported by the opinion of Mantell et al.[14] explaining that cell differentiation is influenced by the relative balance of auxins and cytokines both in culture media and which are naturally contained in plant tissue. This is in confirmation with the earlier study by Reshi et al. [15] observing the in vitro Micropropagation of Anisochilus carnosus (L) wall and revealed that more effect can be gained through combinations of BAP and auxin on multiple shoot induction, compared to BAP or auxins when used separately. 
In the test result, the relationship between explant cuts and concentration of growth regulators used, the best percentage of growth in seen for the treatment of middle bulb explant cuts with all concentrations of growth regulators (Table 3 ).

\subsection{Growing time}

Further test shows significantly different results with the fastest growing time on the base and middle explant cuts compared to the tip cuts. Growing time on bulb explants is related to the presence of natural food reserve substances and natural endogenous growth regulators found in the bulbs. The success of a plant in growth is influenced by genetic and environmental factors. Genetic factors are related to the inheritance of plant traits derived from the parent plant, while environmental factors are related to the environmental conditions in which the plants grow [16]

In the treatment of growth regulators, the treatments for growing time variables showed that there was no significant difference in growing time based on differences in concentration.

The linkage testing of the explant parts and the concentration of growth regulators in the variable of growing time showed significantly different results from the average number of shoots at the $1 \mathrm{mg}$ treatment.

\subsection{Number of shoots}

The average results of number of shoots in the treatment of bulb explant cuts show that the most shoots can be found in the middle and base explant cuts compared to the tip ones (Table 1). Mantell et al. [14] reported that many micro lily shoots were formed at the base of the bulb scales. Furthermore, Liu and Burger [6] reported differences in the response of the formation of micro shoots in explants of lily stalks in the pedicle and receptacle parts. Micro lily shoots are more common in the receptacle than in the pedicle.

The formation process of shoots begins with a rounded swelling on the bulb scale cuts due to internal changes and cell division in parenchymatic sub-epidermal tissue [4]. Leaf tips continue to elongate to form leaf blade (lamina) and leaf midrib, followed by the formation of new leaf strands. Furthermore, in a short time (about 2 weeks) after the appearance of the first leaf blade, roots emerge at the base of the micro shoots. Morphologically, the composition and shape of leaf strands in micro shoots resulting from in vitro culture are similar to shoots produced from lily bulbs in the field. However, 
there are fundamental differences in the pattern of its formation. Lily shoots in the field are produced from bulbs which are preceded by the formation of bulb scales, but micro shoots are produced in vitro without preceding the formation of bulbs or micro bulbs.

In the treatment of growth regulator substance concentration on the variable of the number of shoots, the highest number of shoots was found in $1 \mathrm{mg} \mathrm{L}^{-1}$ NAA and $1 \mathrm{mg} \mathrm{L}^{-1}$ BAP followed by $0.5 \mathrm{mg} \mathrm{L}^{-1} \mathrm{NAA}$ and BAP and treatment of $0.5 \mathrm{mg}$ $\mathrm{L}^{-1} \mathrm{NAA}$ and $1 \mathrm{mg} \mathrm{L}^{-1}$ BAP (Table 2 and Fig. 1). Sun et al. [17] also showed that in the culture of micro bulb explants in Lilium lancifolium, successful growth of shoots were observed in a combination of MS media treatment with the addition of growth regulators of $1 \mathrm{mg} \mathrm{L}^{-1} \mathrm{NAA}$ and $0.1 \mathrm{mg} \mathrm{L}^{-1} \mathrm{BA}$ (auxin and cytokinin). Application of BA-6-benzylaminopurine (6-BA) as a cytokinin application can increase meristem formation and shoot proliferation in many species. Likewise, Yun et al. [18] studied that administration of 6-BA, a-naphthaleneacetic acid (NAA) and sucrose in the development of $L$. lancifolium was very effective in producing regeneration and induction of shoot propagation.

Auxin growth regulator substances such as NAA functions in increasing osmotic pressure, cell permeability, protein synthesis, plasticity and developing cell walls and reducing pressure on cell walls In addition. Auxin plays a role in stimulating cell lengthening and enlargement, while cytokinin such as BAP functions in cell division. In conjunction with cell permeability, auxin increases the diffusion of water into the cell. The combination of auxin and cytokinin will stimulate cell division and affect the path of differentiation [19]. Fonnesbech [20] states that auxin does not function if it does not interact with other hormones. Meanwhile, Morel [21] states that the best concentrations used are 1 ppm cytokinin and 1 ppm NAA.

The concentration of growth regulators with the lowest average number of shoots was in the treatment of $O$ NAA and BAP and $0.5 \mathrm{mg} \mathrm{L}^{-1} \mathrm{NAA}$ and $1 \mathrm{mg} \mathrm{L}^{-1}$ BAP. This shows that BAP accumulation in mini bulb scales is very high so that it inhibits the formation of micro shoots. Winarsih et al. [7] reported that high BAP concentrations inhibited the formation of micro shoots but encouraged bulb formation in the culture of lily bulb scales. Joseph et al., [25], showed that the study a procedure for in vitro production of bulbs of Cyrtanthus mackenii was developed from triscales has been reported that auxin is an effective for shoot induction and in combination with a cytokinin is essential for shoot induction.

Duncan's test results show that interaction between bulb explant cuts and the concentrations of growth regulators showed significantly different results with the average number of shoots at the highest concentration of $1 \mathrm{mg}$. Because of the natural content 
of growth regulators in the bulbs, especially most collected in the middle and base cuts which are close to the meristematic part of the tissue can trigger better growth. In addition, adding appropriate synthetic growth regulators will encourage the growth of more shoots. Winarsih et al. [7] state that the content and relative balance of endogenous growth regulators (auxin and cytokinin) on lily bulb scales have high potential to regenerate to form shoots and bulblets, so that adding appropriate growth regulators in the culture medium, the potential can be expressed.

\subsection{Number of micro bulbs}

Duncan's test results on the number of micro bulbs in the explant cuts show no significant difference. Formation of micro bulbs is characterized by the formation of small yellowish white spots. The spots are enlarged into small brownish spheres. Furthermore, small bulb scales begin to appear when the small dots have a diameter of 2-3 mm. The outer bulb scales continue to enlarge and are followed by the formation of new bulb scales from the point of growth. Along with the long culture, the micro bulbs turned green. Thus, the resulting bulb is composed of several micro bulb scales. The shape and arrangement of the mini bulb scales on the bulblets is the same as the shape and arrangement of the bulb scales on the lily bulbs that are produced naturally in eight ponds [3].

In the treatment of growth regulators concentration on the variable number of micro bulbs, Duncan test results show significantly different results, with the best result was found on the concentration of growth regulators $0.5 \mathrm{mg} \mathrm{L}^{-1} \mathrm{NAA}$ and $1 \mathrm{mg} \mathrm{L}^{-1}$ BAP (fig. 2). Growth regulators of low concentration BAP was combined with NAA for the formation of micro shoots, while high concentrations of BAP both with and without the addition of NAA was used for micro bulb formation [7]. Plant tissue respond differently to auxin and cytokinin, this situation can be used in the regeneration process. Decruse et al. state that the combination of a comparative treatment between auxin and cytokinin is very influential in determining the type of morphogenesis.

Based on the results of the interaction test of 2 factors, bulb explant cuts with concentrations of growth regulators, the average number of micro bulbs was found in the treatment of $0.5 \mathrm{mg} \mathrm{L}^{-1} \mathrm{NAA}$ and $1 \mathrm{mg} \mathrm{L}^{-1}$ BAP with middle explant cuts. With the presence of endogenous growth regulators in bulbs and the addition of exogenous growth regulators, it is able to trigger the growth of micro bulbs. Exogenous growth regulator concentrations that support the growth of micro bulbs are cytokinin. Phytohormone works synergistically with other growth hormones in stimulating growth. 
Natural cytokinin produced in plant tissues work synergistically with NAA and which are synthetic auxins and BAP which are synthetic cytokinin given in this experiment are important in regulating cell division and play an important role in the formation of direct somatic embryogenesis [22]

\subsection{Formation time of micro bulbs}

Duncan test results at the time the micro bulbs were formed in the explant cuts show that there was no significant difference. Lily tuber or bulbs scale organs already have natural endogenous growth regulators to trigger growth, but in pieces the bulbs parts there was no significant difference on the time of the formation of the tubers. Therefore when added to the exogenous growth regulator will further trigger the formation of micro tubers more quickly. Addition of auxin or cytokines to culture media can increase the concentration of endogenous growth regulators in cells, so that it becomes a trigger factor growth in the process of growing and developing tissue [23].

In the treatment of growth regulators concentration for the variable of formation time of micro bulbs, the Duncan test shows significantly different results with the best results at the concentration of growth regulators $1 \mathrm{mg} \mathrm{L}^{-1} \mathrm{NAA}+0.5 \mathrm{mg} \mathrm{L}^{-1}$ BAP. Based on the results of the interaction test of 2 factors for bulb explant cuts with concentrations of growth regulators, the average result of micro bulbs was formed, namely in the treatment of $1 \mathrm{mg} \mathrm{L}^{-1} \mathrm{NAA}$ and BAP with middle bulb explants cuts and treatment concentrations of $0.5 \mathrm{mg} \mathrm{L}^{-1} \mathrm{NAA}$ and BAP in the base explant cuts.

In all geophytes like tulip, lily, hyacinths and iris, the formation of storage organs or growth in vitro is a slow and has problematic process. Although micro propagation protocols have been developed, most are not quite workable in commercial laboratories. Therefore, more research is needed to study and improve in vitro storage organ formation [24]. This study shows an excellent regeneration capacity for L. longiflorum success with in vitro formation shows that the micro bulb culture is an effective and useful technique for propagation of this species. Mass production through tissue culture can also be a desirable alternative for multiplication of seedlings in a short amount of time. The conventional method through seed multiplication requires a longer time, has a low germination rate and a slow growth process. 


\section{Conclusions}

Based on the research results of in vitro propagation of Lilium longflorum bulbs using various treatments of administering growth regulators and bulb explant cuts, it can be concluded that the explants with the best growth response are base and middle bulb explant cuts compared to the tip cuts. The results of the growth percentage, the number of shoots and the best growing time are shown in the combination treatment of $1 \mathrm{mg} \mathrm{L}^{-1} \mathrm{NAA}$ and $1 \mathrm{mg} \mathrm{L}^{-1}$ BAP. The results of the number of micro bulbs are shown in the treatment of $0.5 \mathrm{mg} \mathrm{L}^{-1} \mathrm{NAA}$ and $1 \mathrm{mg} \mathrm{L}^{-1}$ BAP. The results of the average time to form micro bulbs are in the treatment of $1 \mathrm{mg} \mathrm{L}^{-1}$ NAA and BAP with middle explant cuts and treatment concentrations of $0.5 \mathrm{mg} \mathrm{L}^{-1} \mathrm{NAA}$ and BAP in the base explant section. Based on the results of this study, the method of culture propagation of base or middle bulb explant cuts combined with the administration of growth regulator substance can be used as a comparison method for the propagation of lily or other plant species. Therefore when added to the exogenous growth regulator such as auxin or cytokines to culture media will further trigger the formation of micro tubers more quickly. It can increase the concentration of endogenous growth regulators in cells, help growing process and developing tissue. The micro bulb culture is an effective and useful technique propagation for L. longiflorum. Mass production through tissue culture can also be a desirable alternative for multiplication of seedlings in a short amount of time.

\section{References}

[1] Miller, W. B. Easter and Hybrid Lily Production Principles and Practice. Portland Oregon: Timber Press Inc. 1992.

[2] Hoesen DSH., Gandawidjaya J. Lili Bunga Pegunungan. Buletin Kebun Raya Bogor 6(6), 141-147. 1985.

[3] Priyono, Winarsih. Pengaruh Arah Dan Ukuran Potongan Sisik Umbi Kerk Lily (Lilium longiflorum Thunb.) Terhadap Pembentukan Tunas Mikro Dan Bulblet Secara In Vitro. Berita Biologi. 5(1):85-92. 2000.

[4] Robb SM. The culture of excised tissue from bulb scales of Lilium speciosum Thun. Journal of Experimental Botany 8(24), 348-352. 1957.

[5] Takayama S., Misawa M. Regulation of Organ Formation by Cytokinin and Auxin in Lilium Bulbscale Grown in vitro. Plant Cell Physio. 23, 67-74. 1982. 
[6] Liu L and Burger DW. In Vitro Propagation of Easter Lily from Pedicels. Hort.Sci. 21(6), 1437-1438. 1986.

[7] Winarsih S, Priyono, Zaenudin. Pengaruh Zat Pengatur Tumbuh terhadap Perbanyakan Kerk lili secara in vitro. Jurnal Hortikultura 8(3), 1145-1152. 1998.

[8] Luong MX., Ket NV. Rapid Multiplication of Lilium by Tissue Culture. Proceedings of the Southeast Asian Regional Workshop on Propagation Technique for Commercial Crop of the Tropic. Ho Chi Minh City, Vietnam, 7-12 February 1993. IFS\&BRC. him. 180-189. 1993

[9] Suharjo UKJ, Herison C, Fahrurrozi. Keragaman tanaman kentang varitas Atlantik dan Granola di dataran medium (600 m dpl) Bengkulu pasca iradiasi sinar gammat. Akta Agrosia. vol 13(1): 82-88. 2010.

[10] Zakaria RA, Zanjani BM, Sedghi E. Effect of in vitro chitosan application on growth and minituber yield of Solanum tuberosum L. Plant Soil Env. vol 55 (6): 252-256. 2009.

[11] Fufa M and Diro M. Microtuber induction of two potato (Solanum tubersoum L.) varities. Adv. Crop Sci. Tech. vol 2(2): 122. 2014.

[12] Dhaka M., Nailwal TK. High efficienty macropropagation of potato (Solanum tuberosum L.) cv. Kufru Jyoti in Kumaun Hills. J. Plant Breeding and Crop Sci. vol 7(7): 203-210. 2015.

[13] Kanchanapooma K., Tidarat P., Wimon W., Kamnoon K. Regeneration of lily (Lilium longiflorum 'Easter lily') by callus derived from leaf explants cultured in vitro. ScienceAsia 37 (2011): 373--376. 2011.

[14] Mantell SH, Matthews JA, McKee RA. Principal of Plant Biotechnology. Blackwell Scientific Publication. Oxford. 269p. 1985.

[15] Reshi, N. A., Sudarshana M. S., Girish H. V. In Vitro Micropropagation of Anisochilus carnosus (L) Wall. Journal of Applied Pharmaceutical Science Vol. 7 (07), pp. 098-102. 2017.

[16] Gardner, F.P.,R.B. Pearce, dan R.L. Mitchell. Fisiologi Tanaman Budidaya. Jakarta: UI Press. 1991.

[17] Sun, L., Zhongze Z., Kemeng C. Micropropagation from in vitro cultured bulb scales of Lilium lancifolium. Life Science Journal 10 (2); 2689-2692. 2013.

[18] Yun SY., Lee MS., Lim SC., Shin JD. Micropropagation of Heloniopsis orientalis (Thunb.).C. Tanaka in-vitro. Kor J. Plant Tiss Cult. 27:197-202. 2000.

[19] Thomas, TD., Chaturvedi, R. Endosperm culture: a novel method for triploid plant production', Plant Cell Tissue and Organ Culture, vol. 93, pp. 1-14. 2008. 
[20] Fonnesbech, M. Growth hormone and propagation of Cymbidium in vitro. Physiol. Plant., vol. 27, pp. 310-16. 1992.

[21] Morel, GM. Clonal multiplication of orchid In Withner, CL(ed.)., New York: The orchids scientific studies, Wiley-Interscience Publication, John Wiley \& Sons pp. 169-22. 1974.

[22] Lan, TH, Hong, PL, Huang, CC, Chang, WC \& Lin, CS. High frequency direct somatic embryogenesis from leaf tissues of Drimiopsis kirkii Baker (giant squill). In vitro Cell. Dev. Biol. Plant., vol. 45, pp. 44-7. 2009.

[23] Lestari, E. G.Peranan Zat Pengatur Tumbuh dalam Perbanyakan Tanaman Melalui Kultur Jaringan. Jurnal AgroBiogen.,vol.7,no.1, pp.63-68, 2011.

[24] Askari, N., Richard G.F. Visser, Geert-Jan De K. Growth of Lily Bulblets In Vitro, a Review. International Journal of Horticultural Science and Technology Vol. 5(2); pp 133-143. 2018.

[25] Joseph, S., Lekha K., Narmatha BV. Micropropagation of Cyrtanthus mackenii Hook. $f$ from tri scales. European Journal of Biotechnology and Bioscience. Volume 4(8): 67-72. 2016. 